\title{
Potato Production and Marketing by Small Holder Farmers in Ethiopia: A Review Study
}

\author{
Dawit Milkias $^{1 *} \quad$ Alemayehu Keba ${ }^{2}$ \\ 1.Ambo Agricultural Research Center, P.O.B 37, Ambo, Ethiopia. \\ 2.Ethiopian Institute of Agricultural Research Addis Ababa, Ethiopia
}

\begin{abstract}
Potato (Solanum Tuberosum L.) was originated in the central high lands of the Andes in South America and was brought to Europe in the 16th century. It is the world's fourth most widely cultivated food crop after wheat, rice and maize. Ethiopia has considerable potential for potato cultivation, as 70 percent of its arable land is suitable mainly highland areas above 1500 meters of altitude. Also, the country is one of the major producers in Eastern Africa because of its suitable agro-ecology and its domestic consumption levels. The main objective of the review was to know potato production and marketing status by small holder farmers in Ethiopia. The data were collected from secondary sources mainly from FAOSTAT, CSA and different published materials on production and marketing chain in Ethiopia. The general idea of the review shows that Ethiopia has potential for potato production but lack of certified improved seed for potato producers, local seed multipliers have limited access to information and depend on low-quality local potato varieties selected and multiplied according to individual knowledge, the high cost of agro-chemicals either refuse to purchase fertilizer or apply inadequate amounts per hectare. In addition, the use of the same type of chemicals repeatedly allows pests and diseases to develop resistance. The major constraints of potato marketing involve poor storage and handling and low upgrading strategies to the commodity. Lack of market information providing institutions, higher input price, multiple taxes, and chemical herbicides, adulteration, absence of road service, poor product quality and high cost of input, weak market linkages among market. Therefore, the government and other concerned bodies should focus on increasing production and productivity of potato which in turn focused for establishing well potato market development for mutual benefits of all actors.
\end{abstract}

Keywords: Potato, Production, Marketing, Ethiopia

DOI: $10.7176 / \mathrm{JNSR} / 12-16-02$

Publication date:August $31^{\text {st }} 2021$

\section{Introduction}

Agriculture is the most important sector in Ethiopia; it accounts for 46\% of GDP, $80 \%$ of export value, and about $73 \%$ of employment. The sector still remains largely dominated by rain-fed subsistence farming by smallholders who cultivate an average land holding of less than a hectare. Although agriculture has a long history in the country economy, development of the sector has been hampered by a range of constrains which include land degradation, low technological inputs, weak institutions, and lack of appropriate and effective agricultural policies and strategies (Aklilu, 2015). Vegetable production plays important role in creating new employment opportunities for poor farmers and improving the feeding habit of the people. Since the labor to land ratio of vegetable cultivation is high (require intensive cultivation), its production and marketing activity allows high productive employment (Bezabih and Hadera, 2007). So, increasing vegetable production and marketing thus contributes to increase the income of the rural economy and food security.

Potato (Solanum Tuberosum L.) was originated in the central high lands of the Andes in South America and was brought to Europe in the 16th century. It is the world's fourth most widely cultivated food crop after wheat, rice and maize. It is one of the fastest expanding food crops in Sub-Saharan Africa and a nutritionally balanced food, which provides a high calorie intake and a substantial amount of vitamins. The crop was introduced to Ethiopia in 1859 by a German Scientist called Schimper (Pankrust, 1964). Since then it was limited to homestead as a garden crop and gradual rise in production occurred at the end of 19th century, when there was a long famine in Ethiopia (Gebremedhin et al., 2008). Potato is one of the major food and cash crop in Ethiopia especially in the high and mid altitude areas. It is among the leading vegetable crops in Ethiopia. About 164,146 hectare of land was covered by potato and more than 940,209 tones were produced in Ethiopia in 2001 (Tesfaye, 2008).

Ethiopia has considerable potential for potato cultivation, as 70 percent of its arable land is suitable - mainly highland areas above 1500 meters of altitude. Also, the country is one of the major producers in Eastern Africa because of its suitable agro-ecology and its domestic consumption levels (FAO 2019). Due to its importance as source of food and employment, the Government of Ethiopia considers potato as one of the strategic commodities for ensuring food security in the country. In recent years, potato production has increased significantly, as well as the number of households engaged in and the area of land covered by its production. It is well known that different household attributes put households under different production and marketing 
potentials. The market challenges of that the households face might influence the households/ farmers' participation decision and the extent of participation, the type of vegetable crops they would like to grow and the size of farmland they would like to allocate to a specific crop. This could be due to the fact that production and marketing decisions of households are two sides of a coin. The two decisions go hand in hand as farmers' produce what they could sell at an available market. Knowing the interaction patterns between the two decisions helps to understand what crop is sold at which market and whether the intention of selling at a particular outlet increases or decreases the size of farmland allocated to the specific crop. Imperfections in markets and asymmetric market price information hinder the potential gain that could have been attained under the existence of markets with complete information. In this regard, marketing vegetable crops at farm-gate is an interesting process that has not been investigated much. Both buyers and sellers usually do not have equal market information on the vegetable prices at the central market. Under such circumstances, farm households selling vegetable crops at farm-gate deal with the trade-off between selling their crop harvests at higher possible prices and avoiding the risk of losing product quality if the transaction fails by holding on to higher prices. An interesting issue in this regard is what factors determine the farmers' to gross margin in the vegetables market.

As efficient, integrated, and responsive market mechanism is of critical importance for optimal area of resources in agriculture and in stimulating farmers' to increase their output. A good marketing system is not limited to stimulation of consumption, but it also increases production by seeking additional output. However, there is a critical problem that stands in the course of formulating appropriate policies and procedures for the purpose of increasing marketing efficiency. This has to do with lack of pertinent marketing information and other marketing facilities, like storage, transportation, etc. Thus, reducing the information gap on the subject by contributing to better understand on improved strategies for reorienting marketing system for the benefit of small farmer development.

\section{Objectives of the Review}

The general objective of this review is to know potato production and marketing status by small holder farmers in Ethiopia with the following specific objectives: to review the production and productivity of potato in Ethiopia, to review major Marketing actors and function of Potato in Ethiopia and to review the constraints and opportunities of Potato marketing in Ethiopia

\section{LITERATURE REVIEW}

\section{History and Overview of Potato production and productivity in Ethiopia}

Potato was introduced to Ethiopia in 1858 by a German immigrant, Wilhelm Schimper, adoption by Ethiopian farmers occurred very gradually for several decades. The first available potatoes were probably of a very limited genetic base, hence vulnerable to diseases and pests. Cultivation was limited to potatoes growing voluntarily in fields in the colder highlands until wider adoption of the potato occurred at the end of the $19^{\text {th }}$ century in response to a prolonged famine. In the 1980's IPM introduced the variety "Cara" to Ethiopia. Cara is still the only European variety being planted in some regions due to its great resistance to blight, robustness and yield potential (IPM, 2015). Potato in Ethiopia is currently planted in around 59,508.67 ha (CSA, 2012). This implies that average yield in the country reaches only $7 \mathrm{t} / \mathrm{ha}$ when the potential for small holder is around $25 \mathrm{t} / \mathrm{ha}$. Potato is the fastest growing food crop in Sub-Saharan Africa and it is an important crop for food security in parts of Ethiopia by virtue of its ability to mature earlier than most other crops at time of critical food need (Haverkortet et al, 2012; Asresie et al, 2015).

According to (CSA, 2016) in Ethiopia, potato ranks first in the category of root and tuber crops (RTCs) in terms of area coverage and total production. Crop production survey results of private peasant holding of the year 2015/16 indicated that of the total land areas of about 496, 148.99 hectares covered by RTCs, 296, 578 hectare $(\sim 60 \%)$ and of over 7.21 million tons of RTCs produced over 3.67 million tons $(\sim 51 \%)$ was potato with an average national yield of $13.9 \mathrm{t} \mathrm{ha}^{-1}$ (CSA, 2017/18).

The author (Gildemacher, et al., 2009) result showed that in Ethiopia several varieties of potato are grown by farmers some of which are local and others are improved varieties. About 20 varieties have been reported to be grown in different parts of Ethiopia. According to CSA (2017) from a total area of 66,923.33 hectares covered by potato 9,214,031.85qt was produced with yield of 137.68qt/ha in Maher season. From these Oromia, Amhara, SNNP and Tigray region covers in production and yields of 4,448,886.23(123.88qt/ha), 2,797,902.49qt (153.85qt/ha), 1,816,761.1qt (155.26qt/ha) and 50,387.59qt (80.96qt/ha) respectively. 
Table 1: The three years history of potato production in Ethiopia.

\begin{tabular}{|l|c|c|c|}
\hline \multicolumn{1}{|c|}{ Potato } & $\mathbf{2 0 1 7}$ & $\mathbf{2 0 1 8}$ & $\mathbf{2 0 1 9}$ \\
\hline Area harvested & $69,611.00$ & $66,635.00$ & $70,362.00$ \\
\hline Production & $968,970.00$ & $933,109.00$ & $924,528.00$ \\
\hline Yield (qt/ha) & 13.92 & 14.00 & 13.14 \\
\hline
\end{tabular}

\section{Source: FAO (2020)}

According to the above table, the yield of potato production per hectare and the used area by hectare throughout the region of Ethiopian country were increasing respectively within three past years. Then the percentage change of yield of potato from 2017 to 2018 was increased by $0.60 \%$ and the yield of potato from 2018 to 2019 was decreased by $6.17 \%$. This decrease in the yield in 2019 is because of the drought encountered in some areas of the country.

(CSA, 2015) report that in Ethiopia potato is grown in four major areas: North-Western, Central, Southern and Benishangul-Gumuz regions. In North-West area, the average yield of the crop ranges from 14 to 15 ton per hectare. South and North Gonder, East Gojjam, West Gojjam and Agew and Awi are the major potato production Zones. In Ethiopia, potato is produced in two season's i.e. in 'belg' season (March- August) and in 'meher' season (September-February). However, most of the production takes place in 'meher' season. Therefore, the season from September to February (i.e. 'Meher' season) is considered as the main season for which most of the information regarding potato production is available.

According to (FAO, 2008), Potato holds a huge (largely ignored) promise for improving the livelihoods of hundreds-of-thousands of smallholder farmers in Ethiopia's risk-prone highlands. Potato is a very important food and cash crops, especially in the high and mid altitude areas of Ethiopia. It has a promising prospect in improving the quality of the basic diet in both rural and urban areas of the country. Potato has high potential for improving food security, increasing household income and poverty reduction as well as provides important nutrients. It has a high content of carbohydrates, significant amounts of quality protein, and substantial amounts of vitamins, especially vitamin C.

Kolech et al., 2015 result indicated that, in Ethiopia, potato is grown in a wide range of agro-ecological zones, throughout the year using different growing practices and is considered a "hunger breaking crop" because it can be grown and harvested when cereals don't mature for consumption other crops fail. Indeed, potato is the only food crop grown to any large extent in the dry season where rain-fall is erratic and unpredictable in the months of March through May. According to the author Egata (2019) described that among African countries, Ethiopia has the most potential of potato production because of the highlands comprises $70 \%$ of the country and home to higher percent of the population. Exploiting these production potentials will make the potato crop to play a key role in ensuring national food security (FAO, 2008). It is an important food crop after cereals, in human diet in developed as well as in developing countries (Wheeler, 2009; Kushwaha et al., 2014). It also goes beyond wheat, rice and maize in terms of dry matter and protein production of per unit of area. According to (Hirpa et al, 2010) the major limiting factors to potato productivity in Ethiopia include lack of high yielding varieties, diseases, post-harvest losses due to poor handling and storage facilities, insufficient clean potato seed tubers, poor seed distribution system, and inadequate production technologies. Amongst these factors, postharvest losses due to poor handling, poor storage facilities and lack of value addition activities are the main potato production constraint in Ethiopia.

The results of (Gebremedhin, 2013) showed that potato's production is constrained by a wide range of factors that resulting in low yields. These factors include lack of high yielding varieties tolerant to late blight, poor soil fertility, climatic limitation, inadequate seeds, lack of appropriate cultural practices, poor post-harvest management \& storage problems, and high cost of farm inputs, diseases and insect pests.

According to (Gildemacher et al., 2009, Mulatu et al., 2005) in Ethiopia, potato has increasingly become a source of cash income for farmers, and retains its importance for household consumption. Despite the benefits of improved potato varieties (enhanced yield and disease resistance), Ethiopian farmers are often reluctant to grow them. This is despite the efforts of the Ethiopian Institute of Agricultural Research (EIAR) which, with support from the International Potato Center (CIP), has distributed 18 improved potato varieties in the last two decades in an attempt to improve the performance of the potato sector (Gebremedhin et al., 2008). However, the rate of adoption of these improved potato varieties by ware potato farmers (farmers who grow potato for consumption rather than for seed) has been very low. Out of the total land allotted to potato production, only $0.5 \%$ of the land was covered by improved varieties in the 2013 main season (CSA, 2014).

According to (Gebremedhin et al., 2008) the Ethiopian Institute of Agricultural Research recognizes the problem with low adoption rates by ware potato farmers, although the causes have not been fully investigated. For example, the EIAR mentions shortage of improved seeds and poor supply systems as the main limiting factors. This assumes that adoption is low because of supply problems and potential adopters do not have access to improved potato varieties. However, this view is not supported by empirical evidence. 


\section{Marketing of potato in Ethiopia}

Markets are important for economic growth and sustainable development of a given country, but, emphases in development policies in agrarian countries have usually been placed on increasing agricultural production to serve as a base for rural development (Chernet Worku et al., 2020). In the absence of well-functioning markets, agricultural production can experience several drawbacks (Mohammed Urgessa. 2011). According (Tekalign, 2010) Potato is among the major vegetable export products (EEI, 2015). It is traded in local market and export market outlets largely to Djibouti, which is an essential activity of the farming households where it generates income and has contributed to the development of potato sector. For instance; increasing of export of potato to Somaliland and Djibouti is major motive for potato farmers in Eastern Ethiopia (Bezabih and Hadera, 2007).

Around 80 to $90 \%$ of the total volume and value of potato exported to Djibouti. The second biggest export country is Somalia, which accounts for 8 and 15\%. The remainder of the export is to Sudan, Yemen and Saudi Arabia. The export of ware potato, both in quantity/volume and value is increasing. E.g. the volume in 2001 was approximately 6,000 tons in 2010 this had reached 21.555 and 71,893 tons in 2015 . The bulk of the potato products exported by Ethiopia are fresh or chilled potatoes, followed by frozen potatoes and a relatively small portion of seed potato. According to (Zhang et al., 2012) Potato, which is available for home consumption is found in different forms throughout the country. Fresh and processed potato are found in graded, washed, sorted, packed, branded forms. Frozen crisps (locally made, imported from whole potato or reconstituted) in supermarkets; boiled or fried potato at home; chips at restaurants are found in the urban areas of Ethiopia. The demand of chips is increasing in urban part of the country (CIP, 2008). The author (Urquieta 2009) further identified that distance from the farm to nearest road, access to information through use of cell phone, age of household head and quantity of potato produced has a significant effect on potato market channel choices.

(FAO, 2007) result suggests that, among African countries, Ethiopia has possibly the greatest potential for potato production. $70 \%$ of its arable land mainly in highland areas above $1500 \mathrm{~m}$ is believed suitable for potato. Since the highlands are also home to almost 90 percent of Ethiopia's population, the potato could play a key role in ensuring national food security. Potato is still widely regarded as a secondary crop, and annual per capita consumption is estimated at just $5 \mathrm{~kg}$.

Addis Ababa is the main market for potatoes produced in Central-Eastern Oromia, while other important markets are major cities like Adama, Bishoftu, Hawassa and Shashamene. Ethiopia exports mainly fresh and chilled potato, followed by a relative small portion of potato seed. The exports of potato grew substantially in recent years, both in terms of quantity and value. In 2015, Ethiopia exported approximately 71 thousand tons of potato to regional markets. Djibouti is by far the largest market outlet, absorbing approximately 80 to 90 percent of Ethiopian's potato export. Somalia is the second largest market, receiving 8 to 15 percent of the total. Other regional markets such as Sudan, Yemen and Saudi Arabia import small quantities of potatoes from Ethiopia.

\section{Determinants of quantity of potato supplied to the market in Ethiopia}

According to Tilahun (2018) Estimates of the parameters of the variables expected, distance to nearest market affect negatively while use of improved seed, frequency of extension contact, land allocated for potato production and yield affect significantly and positively.

The author Addisu (2016) conducted value chain analysis of vegetables: the case of ejere district, west shoa zone, Oromia national regional state of Ethiopia. In his study he examined determinants of volume of sales of potato using two stages least square (2SLS) method. The result of the model indicated that among hypothesized ten explanatory variables five variables productivity, sex of households, distance from nearest market, access of off/non-farm income and land allocated for potato significantly and positively influence volume sales of potato. According to Bazie (2018) study from the hypothesized variables the result of the multiple linear regression models indicates marketed surplus of potato was significantly affected by distance to all weather roads, number of livestock, potato land size, irrigation access, cash income from other farm activities and lagged price. All of these variables affect marketed surplus positively except distance to all-weather road. According to Abraham (2013) using multiple regression model indicated that marketable supply is significantly affected by access to extension service, access to market information, vegetable farming experience and quantity of potato produced. The result shows that quantity of potato production significantly affected by access to extension service, access to market information, vegetable farming experience, sex of the household head, age of the household head and quantity of fertilizer application. Therefore, these variables require special attention if marketable supply is to be increased.

\section{Marketing channels}

According to (FAW 2019) in Central-Eastern Oromia, agricultural products reach consumers through both informal and formal marketing channels. The informal channel is dominant, especially in rural areas. Smallholder producers sell or exchange potatoes with no regulatory oversight. Non-licensed traders (aggregators) dominate the informal channel, usually determining prices with limited or no transparency due to the lack of 
market alternatives. Smallholder producers sell ware potatoes at low farm-gate prices, due to lack of storage facilities and unavailability of transportation services. Often they are forced to sell their products rapidly to cover for other needs and expenses.

The informal channel is often characterized by the absence of adequate infrastructure for aggregation. This result in major issues related to quantities and quality of potatoes that reach the main markets. Limited storage facilities and poor road conditions lead to considerable post-harvest losses and produce deterioration, which ultimately affects selling prices. On the other hand, the formal channel usually involves primary cooperatives and unions as aggregation points, as well as rural wholesalers and licensed traders that supply institutional buyers and large retailers (e.g. supermarkets) in urban areas.

\section{Market information, prices and grading potato for sale}

According to the authors (Yazie Chanie et al., 2015) result indicated that, farmers' means of getting information about potato price are their neighbours, the market and traders. Agriculture office is the main source of information for farmers for seed potato marketing. Most of the respondent farmers do grade potato for sale based on tuber size, colour, health, maturity stage of tubers and combination of these characters. According to (FAW 2019) Potato is not prone to speculative trading on global markets. Prices are more likely to be set by local supply-and-demand conditions and, being potato in Ethiopia a seasonal crop, prices for ware potatoes in CentralEastern Oromia are volatile. The average farm-gate price for ware potatoes usually ranges between ETB 300 600 per quintal, depending on the season. During over-supply periods, the price may drop to ETB 150 per quintal. In Addis Ababa, one kilogram of ware potato is sold at the retail price of ETB 15. Homemade potato chips without standard packaging are commonly found in urban areas at price of ETB 80 per $\mathrm{kg}$. The factory gate price of locally processed potato chips is around ETB 140 per $\mathrm{kg}$, while their retail price in local supermarkets is approximately ETB 280 per $\mathrm{kg}$. The retail price of imported potato chips at supermarkets and mini-markets is around ETB 700 ETB per kg.

\section{Constraints and opportunities of Potato production and marketing in Ethiopia Production related}

FAW 2019 result indicated that lack of certified improved seed is a major challenge for potato producers in Central-Eastern Oromia. Their volumes of production are insufficient and there is inadequate supply of certified seeds, resulting in shortcomings in seed availability and timeliness of delivery. The utilization of non-certified seeds significantly reduces the productivity of potato. Individual potato producers depend almost entirely on informal sources such as farm-saved seeds (small tubers from the previous harvesting season) from neighbors and relatives and from local markets. Local seed multipliers have limited access to information and depend on low-quality local potato varieties selected and multiplied according to individual knowledge.

The high cost of agro-chemicals limits their use and potato producers either refuse to purchase fertilizer or apply inadequate amounts per hectare. In addition, the use of the same type of chemicals repeatedly allows pests and diseases to develop resistance. There is limited availability of pesticides and fungicides both in quality and quantity and producers have limited knowledge on type, dosage, application techniques and timing. The frequency of potato diseases such as late blight (caused by P. infestans) is a major issue, contributing in poor potato yields and huge post-harvest losses. Also, producers in rural areas have insufficient knowledge of good agronomic techniques (e.g. planting, weeding, harvesting, etc.) for business-oriented commercial potato production.

FAW 2019 observed that the use of irrigation is limited to certain parts of Central-Eastern Oromia; in many areas potato production is rain-fed. Diffusion of modern irrigation technologies is very limited with serious consequences related to utilization (overconsumption and misdistribution) of available water resources. Mechanized agriculture is limited primarily because technology importation tariffs are unsustainable and, additionally, land fragmentation deters investments from producers operating in small plots of land. The other major constraint in potato production is seasonality. Seasonal production limits profitability because prices are high during the growing period and low during harvesting season. Off-season potato production is limited where irrigation is available.

\section{Opportunities for Upgrading}

The emergence of specialized potato seed producers strongly linked with research institutions would enhance the performances and competitiveness of the potato sub-sector. Potato processing is another opportunity for operational upgrading. According to (FAW 2019, Chernet Worku, 2020) Ethiopia is one of the largest markets for potatoes in Eastern Africa but relies on informal processing and import of processed products to satisfy its local demand. The piloting of an Integrated Agro-Industrial Park will create market opportunities in the near future for producers located within the Agro-Commodities Procurement Zone, and will represent a means to develop the potato value chain in the area. 
Additionally, the informality of the market represents an untapped opportunity as shifting from informal to formal markets will have benefits on the efficiency of the value chain and on the quality and safety of potatoes (traceability). The piloting of the Integrated Agro-Industrial Park initiative will provide the opportunity for formal business-to-business arrangements (e.g. contract farming) between producers and processors.

\section{CONCLUSION AND RECOMMENDATION}

This review conducted in Ethiopia. The main objective of the review was to know potato production and marketing status by small holder farmers in Ethiopia. Potato was introduced to Ethiopia in 1858 by a German immigrant, Wilhelm Schimper, adoption by Ethiopian farmers occurred very gradually for several decades. Potato is one of the major food and cash crop in Ethiopia especially in the high and mid altitude areas. The general idea of the review shows that Ethiopia has potential for potato production but lack of certified improved seed for potato producers, local seed multipliers have limited access to information and depend on low-quality local potato varieties selected and multiplied according to individual knowledge, the high cost of agro-chemicals either refuse to purchase fertilizer or apply inadequate amounts per hectare. In addition, the use of the same type of chemicals repeatedly allows pests and diseases to develop resistance. The major constraints of potato marketing involve poor storage and handling and low upgrading strategies to the commodity. Lack of market information providing institutions, higher input price, multiple taxes, and chemical herbicides, adulteration, absence of road service, poor product quality and high cost of input, weak market linkages among market. Therefore, the government and other concerned bodies should focus on increasing production and productivity of potato which in turn focused for establishing well potato market development for mutual benefits of all actors.

\section{References}

Abraham, T. (2013). Value Chain Analysis of Vegetables: the case of Habro and Kombolcha Woredas in Oromia region, MSc Thesis in Haramaya University, Ethiopia

Aklilu, A. 2015. Institutional Context for Soil Resources Management in Ethiopia: A Review: September 2015, Addis Ababa, Ethiopia

Asresie, H. Alemu, W. Molla, T. Mekonen,T., Abel, A., Seferew,D., Yihenew, G., Desallegn, M. and Tesfaye, A.(2015). Best fit practice manual for potato production and utilization working paper. Bahardar University cascape.

Gebremedhin W, Endale G, Berga L (2008). Root and Tuber Crops. The Untapped Resources. Ethiopian Institute of Agricultural Research (EIAR). Addis Ababa, Ethiopia.

Gebremedhin, W. 2013. Potato variety development strategies and methodologies in Ethiopia. pp. 45-59. In: Seed potato tuber production and dissemination: experiences, challenges, and prospects. Proceeding of the National workshop on seed potato tuber production and dissemination. Bahir Dar, Ethiopia.

Pankrust R (1964). Notes on a history of Ethiopian Agriculture. Ethiopian Observer.

Tesfaye Abebe (eds) (2008). Proceedings of the 1st Amhara Region Regional Workshop on Potato Research and Development: Achievements and Transfer Experiences and Future Directions. Participatory Potato Technology Development and Transfer: Towards Food Security and Improved Livelihoods in the New Millennium, December 20-21, 2007. Amhara Region Agricultural Research Institute. Bahir Dar Ethiopia.

Egata Shunka Tolessa,. 2019. A review on water and nitrogen use efficiency of potato (Solanum tuberosum L.) in relation to its yield and yield components. Archives of Agriculture and Environmental Science, 4(2): 119132, https://dx.doi.org/10.26832/24566632.2019.040201.

FAO. 2009. New light on a hidden treasure, Food and Agriculture Organization, Rome, p. 136.

CSA (Central statistical agency), 2016. Agricultural sample survey, report on area, production and farm management practice of belg season crops for private peasant holdings. Volume V,

Statistical Bulletin 578. Addis Ababa, Ethiopia.

Tesfaye, A., Yigzaw, D., and Ermias, A. 2008. Crop management research and achievement on potato in Amhara Region with special reference to western Amhara parts. Proceeding of the 1stAmhara Region workshop on potato Research Development: achievements, transfer experiences and future directions. 20-21 Dec. 2007, Bahirdar. ARARI. Bahirdar.

Tesfaye, A., Kiflu, B., Chilot, Y., and Gebremedhin, W.G. 2008. Socioeconomics and technology transfer. In: Root and tuber crops: the untapped resources, Gebremedhin W.G.,Endale G.and Berga L. (eds). EIAR, Addis Ababa. 131-152.

Gildemacher, P.R., W. Kaguongo, O. Ortiz, A. Tesfaye, W. Gebremedhin , W.W. Wagoire, R.Kakuhenzire,P.M. Kinyae, M. Nyongesa, P.C. Struik and C. Leeuwis, 2009. Improving Potato Production in Kenya, Uganda and Ethiopia: A System Diagnosis. Potato Research 52: 173-205.

CIP (International Potato Center), 2012.Tackling food insecurity and malnutrition in Ethiopia through diversification. www.sweetpotatoknowledge.org

Hirpa, A., Meuwissen, M.P.M., Agajie, T., Lommen, W.J.M., Lansink, A.O., Admasu, T. and Struick, P.C. 2010. 
Analysis of seed potato systems in Ethiopia. American J. Potato Res. 87(6): 537-552.

CSA (Central Statistical Agency), 2014. Agricultural sample survey report on area and production of major crops. Statistical Bulletin (532), Volume VI, Addis Ababa, Ethiopia. CSA (Central Statistical Agency). 2011. Agricultural Sample Survey. Reportonarea and Production of Major Crops: Private Peasant Holdings, Meher.

CSA (Central Statistical Agency of Ethiopia), 2017. Agricultural Sample Survey. Report on Area and Production of Major Crops.

CSA (Central Statistical Agency of Ethiopia), 2017. Agricultural Sample Survey. Report on Area and Production of Major Crops.

CSA (Central Statistical Authority), 2012. Agricultural sample survey report on area and production of crops (private peasant holdings, meher season). Volume I. CSA,Ababa, Ethiopia. 128 pp.

Bezabih Emana and Hadera Gebremedihin, 2007. Constraints and opportunities of horticulture production and marketing in Eastern Ethiopia. Dry Lands Coordination Group Report

No 46. Grensen 9b. Norway. http://www.fao.org/faostat/en/\#data\%202020

CSA (Central Statistical Authority). (2015). Agriculture Sample Survey 2014/2015 (2007 E.C). Report on Area and Production of Major Crops (Private Peasant holdings, Meher seasons). Addis Ababa Ethiopia, The FDRE statistical bulletin Volume 01-578.

EEI (Ethiopian Export institute). (2015). http://www.ethiopianexporters.com/products.html.

FAO (Food and Agriculture Organization). (2007). Marketing improvement in the developing world. Marketing and Credit Service. Rome, Italy.

Haverkort, A.J., van Koesveld, M.J., Schepers, H.T.A.M., Wijnands, J.H.M., Wustman, R. and Zhang, X.X. (2012). Potato prospects for Ethiopia: on the road to value addition (No. 528).PPO-AGV.

Tekalign. T.(2010). Potato Value Chain Analysis in Eastern Ethiopia: A study conducted as part of a project entitled "Value Chains for Poverty Reduction in the Agri-Food Sector-Problem-Based Learning in Higher Education" which is within the Edulink program of Europe Aid", coordinated by Humboldt Universität zu Berlin, Germany.

Tilahun, Yirgalem. (2018). potato (solanumtuberosum 1.) market chain analysis: the case of sekela district, west gojjam zone, amhara national regional state,An MSc Thesis in Haramaya University. 45-56.

Urquieta, N.R. (2009). Effects of access to information on farmer's market channel choice: The case of potato in Tiraque sub-watershed, Bolivia. M.Sc Thesis, Virginia Polytechnic Institute and State University, Blacksburg, Virginia, USA. 